\title{
Evaluation of Antioxidant, Cytotoxic and Antibacterial Potential of Allium cepa Linn ${ }^{\dagger}$
}

\author{
Rubanaa Jeyakumar ${ }^{1, *}$, Parthiban Murugaiyah ${ }^{1}$, Norliza Shah Jehan Muttiah ${ }^{1}$, Kokila Thiagarajah ${ }^{1}$ \\ 1 Department of Biological Science, Faculty of Science, Tunku Abdul Rahman University, Jalan Universiti Bandar Barat, \\ 31900, Kampar, Perak \\ * Correspondence: norliza@utar.edu.my; \\ $\dagger$ Presented at International e-Conference on Bioengineering for Health and Environment (ICBHE 2020)
}

Received: 5.07.2020; Revised: 10.07.2020; Accepted: 12.07.2020; Published: 15.07.2020

\begin{abstract}
Due to high medicinal qualities, plants are being massively explored in scientific research, and in medical and pharmaceutical industries. Hence, the present study was conducted to determine the antioxidant, cytotoxic and antibacterial properties of Allium cepa Linn. The crude extracts of A. cepa L. showed significant antioxidant property via DPPH Free Radical Scavenging Assay and Iron Chelating Assay, of which ethyl acetate extract demonstrated the highest activity with $\mathrm{EC}_{50}$ value of $41.229 \mu \mathrm{g} / \mathrm{ml}$ and $55.419 \mu \mathrm{g} / \mathrm{ml}$ respectively. Folin-Ciocalteu Reagent Test and Aluminium Chloride Colourimetric Method also revealed the superiority of ethyl acetate in extracting phenolic compounds (70.10 $\mu \mathrm{g} \mathrm{GAE} / \mathrm{mg})$ and flavonoids $(101.28 \mu \mathrm{g} \mathrm{QE} / \mathrm{mg})$. The cytotoxic property of the extracts was tested on human chronic myelogenous leukemia cell line (K562) via 3-(4,5-dimethylthiazol-2-yl)-2,5diphenyltetrazolium bromide (MTT) Assay. Ethyl acetate extract showed good cytotoxicity against K562 cells, having $\mathrm{IC}_{50}$ value of $131.46 \mu \mathrm{g} / \mathrm{ml}, 104.75 \mu \mathrm{g} / \mathrm{ml}$, and $59.91 \mu \mathrm{g} / \mathrm{ml}$ at 24,48 and 72 hours of incubation respectively. Qualitative screening on the antibacterial property of the extracts was carried out via Broth Microdilution Method. Ethyl acetate extract was again proved to exhibit inhibitory and bactericidal activity against Staphylococcus aureus, Enterococcus faecalis, Pseudomonas aeruginosa, and Escherichia coli.
\end{abstract}

Keywords: Antioxidant activity; Cytotoxicity; Cancer cells; Antibacterial activity.

(C) 2020 by the authors. This article is an open-access article distributed under the terms and conditions of the Creative Commons Attribution (CC BY) license (https://creativecommons.org/licenses/by/4.0/).

\section{Funding}

This research received no external funding.

\section{Acknowledgments}

This study was supported by UTAR.

\section{Conflicts of Interest}

The authors declare no conflict of interest. 